This item was submitted to Loughborough's Research Repository by the author.

Items in Figshare are protected by copyright, with all rights reserved, unless otherwise indicated.

\title{
Improved daylight management of historic showrooms: a methodology based on detailed recording and analysis
}

PLEASE CITE THE PUBLISHED VERSION

https://doi.org/10.1080/00393630.2020.1755798

PUBLISHER

Taylor \& Francis

VERSION

AM (Accepted Manuscript)

\section{PUBLISHER STATEMENT}

This is an Accepted Manuscript of an article published by Taylor \& Francis in Studies in Conservation on 4 May 2020, available online: http://www.tandfonline.com/10.1080/00393630.2020.1755798.

LICENCE

CC BY-NC-ND 4.0

\section{REPOSITORY RECORD}

Blades, Nigel, John Mardaljevic, Katy Lithgow, Stephen Cannon-Brookes, Lisa O'Hagen, and Sarah McGrady. 2020. "Improved Daylight Management of Historic Showrooms: A Methodology Based on Detailed Recording and Analysis”. Loughborough University. https://hdl.handle.net/2134/12290690.v1. 


\section{Studies in Conservation}

\section{Improved daylight management of historic showrooms: a methodology based on detailed recording and analysis \\ --Manuscript Draft--}

\begin{tabular}{|c|c|}
\hline Manuscript Number: & SIC1116R2 \\
\hline Full Title: & $\begin{array}{l}\text { Improved daylight management of historic showrooms: a methodology based on detailed } \\
\text { recording and analysis }\end{array}$ \\
\hline Article Type: & IIC Congress 2020: Paper Proposal \\
\hline Section/Category: & IIC Congress 2020: Paper and Poster Proposals \\
\hline Keywords: & daylight; illuminance; historic building; light sensitive; collections; interiors \\
\hline Corresponding Author: & $\begin{array}{l}\text { Nigel Blades } \\
\text { National Trust } \\
\text { UNITED KINGDOM }\end{array}$ \\
\hline \multicolumn{2}{|l|}{$\begin{array}{l}\text { Corresponding Author Secondary } \\
\text { Information: }\end{array}$} \\
\hline Corresponding Author's Institution: & National Trust \\
\hline \multicolumn{2}{|l|}{$\begin{array}{l}\text { Corresponding Author's Secondary } \\
\text { Institution: }\end{array}$} \\
\hline First Author: & Nigel Blades, BSc PhD \\
\hline \multicolumn{2}{|l|}{ First Author Secondary Information: } \\
\hline \multirow[t]{6}{*}{ Order of Authors: } & Nigel Blades, BSc PhD \\
\hline & John Mardaljevic, PhD \\
\hline & Katy Lithgow, MA \\
\hline & Stephen Cannon-Brookes, PhD \\
\hline & Lisa O'Hagan, MSc \\
\hline & Sarah McGrady \\
\hline \multicolumn{2}{|l|}{$\begin{array}{l}\text { Order of Authors Secondary } \\
\text { Information: }\end{array}$} \\
\hline Manuscript Region of Origin: & UNITED KINGDOM \\
\hline Abstract: & $\begin{array}{l}\text { This paper describes a pioneering in situ study of the daylight characteristics of a historic } \\
\text { house interior. A combination of lux measurements inside and outside a historic } \\
\text { showroom and recording of sunshine hours have been used together with a log of the } \\
\text { room blind operation to understand the daylight characteristics of the room under } \\
\text { different weather conditions, blinds settings and season. Average lux, daily luxhour } \\
\text { dose, time below } 30 \text { lux and daylight factor metrics have been derived to assess daylight } \\
\text { conditions over a } 10 \text { month period for both conservation of light sensitive collections and } \\
\text { the viewing experience of visitors. Recommendations are made on how to improve } \\
\text { daylight management for conservation and visitor experience. }\end{array}$ \\
\hline Funding Information: & \\
\hline
\end{tabular}




\section{Improved daylight management of historic showrooms: a methodology based on detailed recording and analysis}

Nigel Blades, John Mardaljevic, Katy Lithgow, Stephen Cannon-Brookes, Lisa O'Hagan and Sarah McGrady

\section{Introduction}

In historic houses managed by the National Trust (NT) and others, daylight is the main source of showroom illumination. As a historically authentic light source daylight contributes variety and interest to the appearance of rooms and their collections. However, it is also the most difficult light source to manage for both visitor enjoyment and conservation of collections. The daily and seasonal variation of daylight, together with the rapid drop in illumination away from windows mean that light levels vary greatly both over time and with location within the room.

In NT properties daylight is controlled using window blinds, managed according to a light plan, by which the blind settings for different times of day and weather conditions are determined from spot readings made at various points in a room. The blind settings are chosen to provide sufficient light to see the room whilst managing daylight exposure within an annual lux hours light budget set for the room (Bullock and Lloyd 2011).

However, the variability of daylight makes it difficult and time-consuming to collect the spot readings needed to characterise room daylight illumination. This paper explores new approaches to this problem using (i) conventional illuminance loggers inside and outside the building and (ii) the novel technique of high dynamic range (HDR) imaging to derive illuminance data for entire wall surfaces from images captured by a digital camera (Cannon-Brookes et al. 2017). Analysis of the HDR data collected is presently underway and will be reported in detail separately.

\section{Case study of the Volury at Ham House}


The Volury, a south-facing ground floor showroom at Ham House, was chosen as a case study (Figure 1) of a seventeenth-century (1610-1670s) structure with smaller window-to-room proportions than the eighteenth-century side-lit Smoking Room studied at Ickworth House (1795-1829) (Cannon-Brookes et al. 2017), or the nineteenth-century top-lit staircase at Mount Stewart, Northern Ireland (after 1804) (Blades et al. 2016), investigated as part of a wider project to assess the NT's current light management procedures, to improve outcomes for collections, staff and visitors. Highly light-sensitive tapestries are displayed in the Volury (named for the birdcages originally placed outside the windows but removed in the eighteenth century). Daylight entering through its bay windows is carefully managed during open hours using two sets of light Holland blinds. Window shutters exclude daylight during closed hours. The aim of the study was to understand how daylight varied with weather and with the blinds, when set according to the Volury light plan, and to determine if there was scope to improve daylight management for both conservation and visitor enjoyment. The information and data collected to this end are given in Table 1.

Three walls of the Volury are hung with tapestries depicting the Life of Pyrrhus by an unknown maker but dated to 1675-1699 (NT 1140014.1-4), after paintings by Poussin. The room and its collections are deemed highly light sensitive, although the gilt furniture upholstery and carpet are modern reproductions. Consequently, the Volury's light exposure is managed to 150,000 lux hours per year in line with the National Trust's collections conservation policy and museum standards - a dose of 150,000 lux hours being equivalent to annual display in a museum at a level of 50 lux (Bullock and Lloyd 2011). Daylight exposure is monitored using a blue wool dosimeter (BWD) at the lower left corner of the tapestry on the west wall (Figure 2).

The Volury's light plan informs the management of its daylight exposure using two sets of cream-coloured Holland blinds according to the scheme in Table 2. These blinds have a light transmittance of about $15 \%$ and the transmitted light is entirely diffused. When the room is closed to visitors the shutters are put in place to exclude daylight completely. The only electric light is from two small table lamps either side of the window bay, which contribute a tiny amount of light at the study measurement points. 


\section{Light plan operation in the Volury}

The Volury is open to visitors every day between 12.00 and 16.00 with very occasional closures for filming. In 2019 the Volury opened 363 days of the year. Winter opening of the ground floor alternates with the first floor, so in 2020 the Volury will close for winter at the end of October, whilst the first floor remains open. The room log showed that on open days the Volury shutters are opened quite early, often by 11.00 , and that they are closed promptly, usually at or just after 16.00 . On most days the blinds were set once at the start of the day, but later in the year the house team would check the blinds settings around 14.00 and adjust them if the weather conditions had changed.

Data for the full year show that $24 \%$ of the Volury light dose is accumulated outside open hours. This is a larger proportion than in many NT properties, which generally aim to use only $10-15 \%$ of their light dose outside open hours. However, assuming that $76 \%$ of the light dose is available for open hours $12.00-16.00$, then the target daily light dose over a year is $76 \%$ of 150,000 lux hours, or 114,000 lux hours, which over 363 open days equates to 314 lux hours per day.

\section{What are the different illuminance characteristics of sunny and overcast days?}

A detailed description of two days, illustrating the range of daylighting conditions, will introduce the broader conclusions drawn (Figure 3). 28 June was a day with continuous direct sunshine as shown by the external illuminance plot. Most of the light received was direct sun with some sky light. There was little variation in the external light level during open hours. In the Volury the two blinds sets were lowered completely to exclude direct sun, so that daylight reaching the interior was entirely diffused by the blinds. In the morning the west wall directly facing the sun received the highest illuminance, over 250 lux. As the sun moved round, the illuminance gradually tailed off, without going below 100 lux. This pattern is mirrored at the NW and NE corner sensors. The mantlepiece sensor on the east wall faces the sun's 
position for most of the opening hours and shows the least variation in illuminance, around 200 lux for most of the day. At these light levels the interior and tapestries are likely to be well illuminated for visitors.

In contrast, 19 June started overcast and the blinds were, therefore, raised completely. The external data show much lower illuminance, a quarter of that on the sunny day. The four Volury measuring points track each other closely, with illuminances of 50-100 lux in the morning, rising to 180 lux when the sun came out between 11.00 and 12.00, suggesting direct sunlight was admitted for a short time. In the afternoon the illuminance fell to 30-50 lux. When cloudy, with the blinds fully raised, viewing conditions are mostly adequate but some visitors may struggle to see the room well.

\section{General daylight performance}

The following metrics have been applied to summarise general daylight performance for the whole monitoring period (Table 3).

Average lux - the range of mean lux values across the four measuring points during open hours.

Lux hours per day - the total light dose received per day. Data presented for the west wall, near the BWD location where the tapestry is closest to the window bay. This represents the most challenging location for conservation.

Minutes per day below 30 lux - time during open hours when the illuminance is below 30 lux. Data are presented for the darkest measuring point, the north east corner. This represents the most challenging location for viewers. 30 lux was selected as a level below which most viewers cannot see colours adequately (Crawford 1973). Whilst 50 lux is more commonly used as a threshold for reasonable viewing in museums, 30 lux was chosen as a light level that may be acceptable at the back of a historic house interior. Research on visitor perception of daylight in NT historic house showrooms will be conducted in 2020-21. 
Daylight factor - percentage of light received on the indoor working plane compared with external global horizontal illuminance, normally measured under diffuse daylight conditions. This metric is used in lighting design, where a predominately daylit working space should have a daylight factor of 2-5\% (CIBSE 2014). The working plane is normally horizontal but for the Volury the vertical plane was used. The total external illuminance measured on the roof of Ham House and the Volury room illuminances were used to calculate the daylight factor. The total external illuminance includes a significant direct sun component when the sky is not overcast, differing from the standard methodology. At these sunny times, however, the light plan dictates that the blinds should be fully down, excluding direct sunlight.

The average lux and time below 30 lux metrics clearly show the difference in daylighting on these two contrasting days. Interesting is the daylight factor - the proportion of outdoor light reaching the interior. Even with the blinds fully up on the overcast day the daylight factor is just $0.1 \%$, a low value compared with modern design specifications, highlighting the very different daylight performance of a historic interior, with darker interior finishes and smaller windows than modern buildings. On the sunny day with both sets of blinds down, the daylight factor is also $0.1 \%$. The higher external illuminance is offset by the blinds reflecting or absorbing most of the light, converting a small proportion to diffuse light which illuminates the interior evenly.

The daily lux hour totals can best be understood by comparing them with the average expected light dose for the room (314 lux hours). The total on a sunny day is significantly above this figure while the overcast day is substantially below it. The annual light dose metric used by the National Trust accommodates this variation. As long as there are enough overcast days to counterbalance days with strong sunshine, it is possible meet the annual light budget, and this indeed appears to be the case in the Volury, where the total annual light dose estimated from data collected from April 2019 to February 2020 was 125,000 lux hours.

To arrive at conclusions that will be useful for managing the Volury's daylight exposure we need to know the general characteristics across the year: how typical are the sunny day conditions observed on the 28 June? How do conditions vary with 
the seasons? To answer these questions, Table 4 summarises all the daily observations, broken down by blind setting and summer and winter season. For each condition we have data for at least 15 days, which should enable robust trends and patterns to be discerned.

In the summer months daylight provides good to adequate viewing, for the most part, the best case being on a sunny day with blinds all down. This does not allow a view out to the garden, which can, however, be seen from other rooms on Ham's south façade. The blind settings on days with direct sun all give daily lux hour totals above the average target value (314 lux hours), but not excessively so. Viewing is less good on very overcast days, such as 19 June, but the average overcast day can still give illuminances over 40 lux. That the average daylight factor is $0.1 \%$ for all the blind settings, suggests the blind positions in the light plan are well-chosen to give similar attenuation of daylight.

In the winter months, sunny days with the blinds closed still provide reasonable viewing with, on average, only 16 minutes of open time below 30 lux. When there is partial sun or a mostly overcast sky, conditions become more problematic with visitors experiencing a level of 30 lux or lower for over 120 minutes - half the open time in a day. In the winter months the daylight factor of $0.2 \%$ is double that in the summer months. This may be because the sun is lower in the sky and its light strikes the south-facing Volury windows and blinds at an angle closer to the normal, which may give more efficient light transmission into the room than when the sun is higher in the sky.

\section{Implications for daylight management}

As the lux hour doses on these days are modest there is scope to raise the blinds to a greater extent under the conditions defined as sunny afternoon, sunny morning, dull some sun and partly overcast, to admit more light for the viewer. However, care should be taken to avoid direct sun falling on the tapestries and other sensitive objects. Opening the shutters nearer to the opening time of the house would also increase the light-dose available during opening hours. Though significant time would be needed to open all the shutters in a large house such as Ham in this way, 
the shutters in south-facing rooms, could be prioritised for opening last and closing first.

The most problematic daylight conditions are on fully overcast days in winter, when illuminance can fall to 20 lux, despite fully raising the blinds. As there is no more daylight to use, supplementary electric lighting could be introduced, and is presently being considered at Ham.

\section{Summary and conclusions}

This analysis of logger data has enabled us to build up a picture of how different weather conditions and blind settings determine the daylight conditions in the Volury. Some improvements in light management have been suggested, but overall the room is managed well at present, if the limitations of very overcast days were addressed with supplementary lighting.

HDR data will enable us to understand the whole illumination field of the Volury tapestries, overcoming the limitations of spot readings in light planning. The methodology developed with the dataloggers will be used with HDR data and applied to understand daylight management in other National Trust showrooms and how this can be simplified for operational staff, improved for viewers, and optimised for the preservation of light-sensitive objects.

\section{Acknowledgements}

The authors would like to thank the house team at Ham for their considerable time and input to the research; and Tim Mason, Senior Building Surveyor, for facilitating installation of the BF5 sunshine sensor on the roof at Ham.

\section{References}

Blades, N., K. Lithgow, S. Cannon-Brookes, and J. Mardaljevic. 2016. "New tools for managing daylight exposure of works of art: case study of Hambletonian, Mount 
Stewart, Northern Ireland." Journal of the Institute of Conservation 40(1): 15-33. https://doi.org/10.1080/19455224.2016.1214610

Bullock, L. and H. Lloyd. 2011. "Light as an agent of deterioration." In National Trust Manual of Housekeeping, 92-100. Swindon: National Trust.

Cannon-Brookes, S., J. Mardaljevic, K. Lithgow, and N. Blades. 2017. "New developments in understanding daylight exposure in heritage interiors." In ICOM-CC 18th Triennial Conference Preprints, Copenhagen, 4-8 September 2017, ed. J. Bridgland, art. 1505. Paris: International Council of Museums.

CIBSE. 2014. Lighting for the Built Environment LG10: Daylight - a guide for designers. London: Society of Light and Lighting.

Crawford, B.H. 1973. "Just perceptible colour differences in relation to level of illumination." Studies in Conservation 18(4): 159-166.

\section{Captions}

Figure 1. Top: south front of Ham House with the Volury bay windows labelled. Bottom: looking into the Volury from the bay windows

Figure 2. Composite image showing lux sensor locations in the Volury, blue wool dosimeter on the far left of the west wall. The HDR camera was located high up in the south east corner with a view of the north and west walls

Figure 3. External and Volury illuminances by hour of the day. Left: 28 June 2019, with continuous sunshine and sunny day blind setting; right: 19 June 2019, a mostly overcast day with fully overcast blind setting. Key to the Volury sensors: west wall (red), NW corner (cyan), NE corner (green), mantlepiece (blue), external sensor total global horizontal illuminance (grey) and direct sun (yellow) 
Table 1. Ham House Volury case study data collected April 2019 to February 2020

Table 2. Blinds settings used in the Volury for daylight management

Table 3. Daylight metrics for contrasting sunny (28 June) and overcast (19 June) days in the Volury, open hours 12.00-16.00. Key to lux distributions: west wall (red), NW corner (cyan), NE corner (green) and mantlepiece (blue)

Table 4. Volury daylighting by blind setting and weather conditions for the spring/summer and autumn/winter seasons, open hours 12.00-16.00. Sunshine sensor data have been used to filter out (i) times without direct sun from the Sunny day figures; and (ii) times with direct sun from the Fully overcast day figures 


\begin{tabular}{|l|l|l|}
\hline Parameter & Method & Recording frequency \\
\hline $\begin{array}{l}\text { Blind } \\
\text { operation }\end{array}$ & $\begin{array}{l}\text { Room log, house staff complete by hand, } \\
\text { noting room open and closing times and blind } \\
\text { positions }\end{array}$ & $\begin{array}{l}\text { Start and end of day, updated in } \\
\text { middle of day if blinds re-set }\end{array}$ \\
\hline $\begin{array}{l}\text { Indoor } \\
\text { illuminance }\end{array}$ & $\begin{array}{l}\text { Hanwell ML4701 radiotelemetric illuminance } \\
\text { sensors on west wall, NW corner, NE corner, } \\
\text { east wall (Figure 2) }\end{array}$ & Five-minute intervals \\
\hline $\begin{array}{l}\text { Indoor } \\
\text { illuminance }\end{array}$ & $\begin{array}{l}\text { High dynamic range imaging - camera installed } \\
\text { above east door with view of west and north } \\
\text { wall tapestries }\end{array}$ & $\begin{array}{l}\text { Set of HDR exposures completed } \\
\text { every 10 minutes }\end{array}$ \\
\hline $\begin{array}{l}\text { Outdoor } \\
\text { illuminance }\end{array}$ & $\begin{array}{l}\text { Delta-T BF5 sunshine sensor on roof recording } \\
\text { diffuse skylight and direct sunlight }\end{array}$ & $\begin{array}{l}\text { One-minute intervals, data } \\
\text { processed to give five-minute } \\
\text { averages }\end{array}$ \\
\hline
\end{tabular}




\begin{tabular}{|c|c|c|}
\hline Weather & Holland blind setting & Depiction \\
\hline $\begin{array}{l}\text { Sunny day - clear sky } \\
\text { conditions all day }\end{array}$ & $\begin{array}{l}\text { Both blinds fully down on all } \\
\text { three windows }\end{array}$ & \\
\hline $\begin{array}{l}\text { Sunny morning - clear sky } \\
\text { and direct sun from the south } \\
\text { east }\end{array}$ & $\begin{array}{l}\text { East and centre windows with } \\
\text { one blind fully down, second } \\
\text { blind } 1 / 2 \text { down; } \\
\text { west window one blind } 1 / 2 \text {, } \\
\text { allowing a view out }\end{array}$ & \\
\hline $\begin{array}{l}\text { Sunny afternoon - clear sky } \\
\text { and direct sun from the south } \\
\text { west }\end{array}$ & $\begin{array}{l}\text { West window both blinds fully } \\
\text { down } \\
\text { East and centre windows one } \\
\text { blind } 3 / 4 \text { down, second blind } 1 / 2 \\
\text { down, allowing a view out }\end{array}$ & \\
\hline $\begin{array}{l}\text { Dull, some sun - variable } \\
\text { conditions with sun likely to } \\
\text { break through from time to } \\
\text { time, so one blind set fully } \\
\text { down to exclude any direct } \\
\text { sun }\end{array}$ & $\begin{array}{l}\text { On all windows: one blind fully } \\
\text { down, second blind } 1 / 2 \text { down }\end{array}$ & \\
\hline $\begin{array}{l}\text { Partly overcast-mostly dull } \\
\text { but with some bright cloud and } \\
\text { occasional sun breakthrough, } \\
\text { half setting limits light from the } \\
\text { bright sky }\end{array}$ & $\begin{array}{l}\text { One blind } 1 / 2 \text { down, second } \\
\text { blind fully up }\end{array}$ & \\
\hline $\begin{array}{l}\text { Fully overcast - thick cloud } \\
\text { that persists through the day }\end{array}$ & Both blinds fully up & \\
\hline
\end{tabular}




\begin{tabular}{|c|c|c|c|c|}
\hline & $\begin{array}{l}\text { Average lux (range of } \\
\text { four measuring point } \\
\text { means); distributions } \\
\text { shown graphically }\end{array}$ & $\begin{array}{c}\text { NE corner } \\
\text { time }<30 \text { lux } \\
\text { (minutes) }\end{array}$ & $\begin{array}{l}\text { Average } \\
\text { daylight } \\
\text { factor (\%) }\end{array}$ & $\begin{array}{c}\text { Daily lux } \\
\text { hours } \\
\text { (west wall) }\end{array}$ \\
\hline $\begin{array}{l}\text { Typical sunny day } \\
\text { (28 June } 2019 \text { ) }\end{array}$ & Lux & 0 & 0.1 & 473 \\
\hline $\begin{array}{l}\text { Typical overcast day } \\
\text { (19 June 2019) }\end{array}$ & 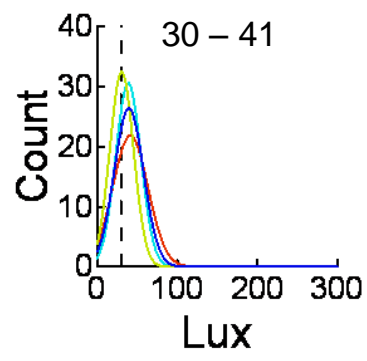 & 150 & 0.1 & 165 \\
\hline
\end{tabular}




\begin{tabular}{|c|c|c|c|c|c|c|c|}
\hline Season & Days & Blind setting & Weather condition & $\begin{array}{c}\text { Average } \\
\text { illuminance } \\
\text { (range across } \\
\text { four measuring } \\
\text { points, lux) }\end{array}$ & $\begin{array}{l}\text { Average time } \\
\text { per day below } \\
30 \text { lux in NE } \\
\text { corner (minutes) }\end{array}$ & $\begin{array}{c}\text { Average } \\
\text { daylight factor } \\
\text { (of four } \\
\text { measuring } \\
\text { points, \%) }\end{array}$ & $\begin{array}{l}\text { Average daily } \\
\text { light dose on } \\
\text { west wall } \\
\text { (lux hours) }\end{array}$ \\
\hline \multirow[t]{4}{*}{$\begin{array}{l}\text { Spring/summer: } \\
\text { Apr-Sep }\end{array}$} & 45 & $\begin{array}{l}\text { Sunny day (both blinds } \\
\text { down) }\end{array}$ & $\begin{array}{l}\text { Continuous } \\
\text { sunshine }\end{array}$ & $94-166$ & 3 & 0.1 & 422 \\
\hline & 34 & $\begin{array}{l}\text { Sunny morning, sunny } \\
\text { afternoon, dull some sun }\end{array}$ & $\begin{array}{l}\text { Times of bright } \\
\text { direct sun and } \\
\text { overcast sky }\end{array}$ & $78-115$ & 34 & 0.1 & 368 \\
\hline & 18 & $\begin{array}{l}\text { Partly overcast (one set } \\
\text { of blinds half down) }\end{array}$ & $\begin{array}{l}\text { Mostly overcast, } \\
\text { some direct sun }\end{array}$ & $66-78$ & 43 & 0.1 & 291 \\
\hline & 15 & $\begin{array}{l}\text { Fully overcast day (all } \\
\text { blinds fully raised) }\end{array}$ & $\begin{array}{l}\text { Sky overcast, no } \\
\text { direct sun }\end{array}$ & $43-56$ & 51 & 0.1 & 207 \\
\hline \multirow[t]{4}{*}{$\begin{array}{l}\text { Autumn/winter: } \\
\text { Oct-Feb }\end{array}$} & 20 & $\begin{array}{l}\text { Sunny day (both blinds } \\
\text { down) }\end{array}$ & $\begin{array}{l}\text { Continuous } \\
\text { sunshine }\end{array}$ & $48-106$ & 16 & 0.2 & 187 \\
\hline & 36 & $\begin{array}{l}\text { Sunny morning, sunny } \\
\text { afternoon, dull some sun }\end{array}$ & $\begin{array}{l}\text { Times of bright } \\
\text { direct sun and } \\
\text { overcast sky }\end{array}$ & $43-64$ & 122 & 0.2 & 139 \\
\hline & 19 & $\begin{array}{l}\text { Partly overcast (one set } \\
\text { of blinds half down) }\end{array}$ & $\begin{array}{l}\text { Mostly overcast, } \\
\text { some direct sun }\end{array}$ & $33-45$ & 138 & 0.2 & 113 \\
\hline & 19 & $\begin{array}{l}\text { Fully overcast day (all } \\
\text { blinds fully raised) }\end{array}$ & $\begin{array}{l}\text { Sky overcast, no } \\
\text { direct sun }\end{array}$ & $18-20$ & 154 & 0.2 & 79 \\
\hline
\end{tabular}




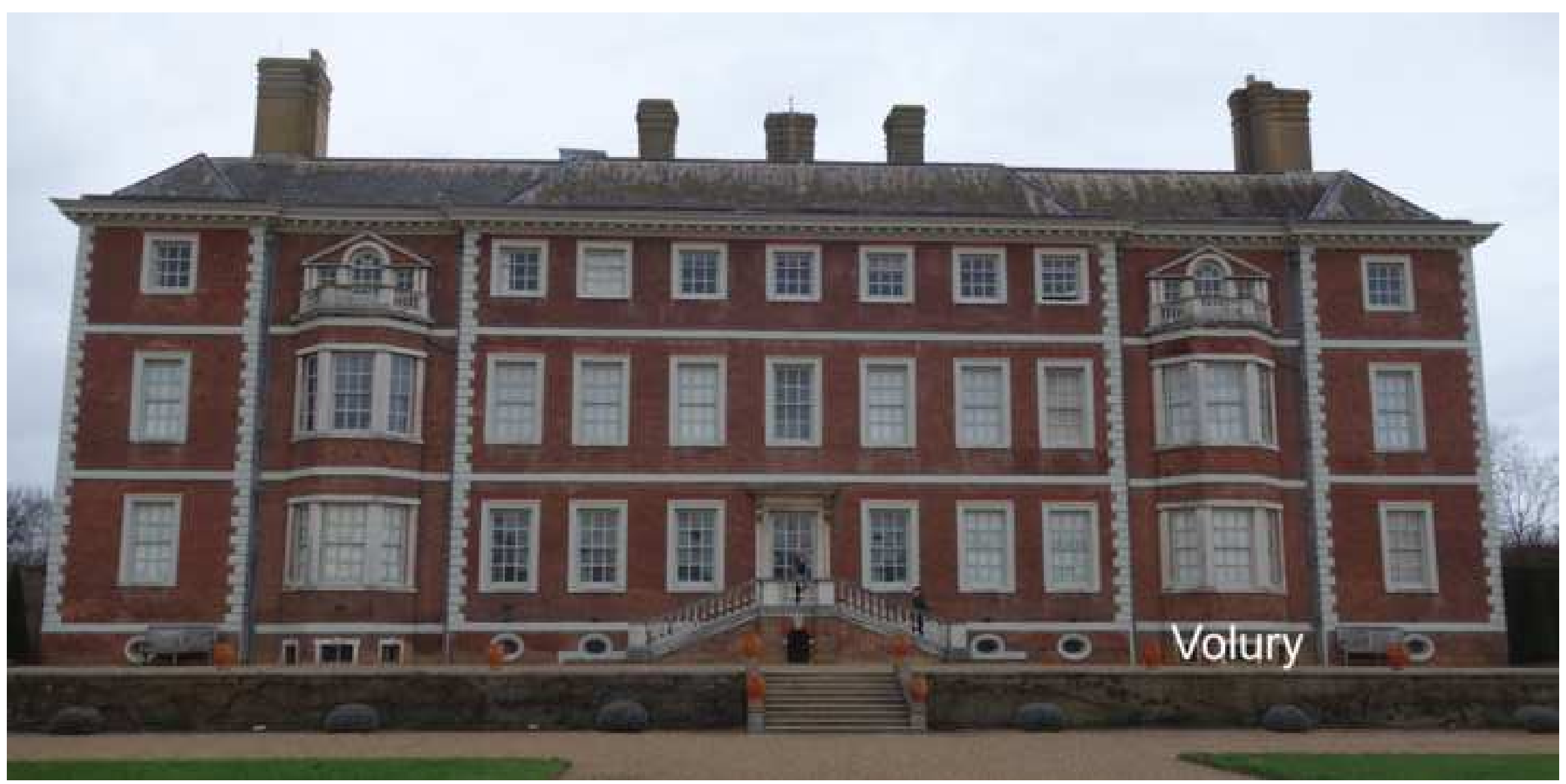




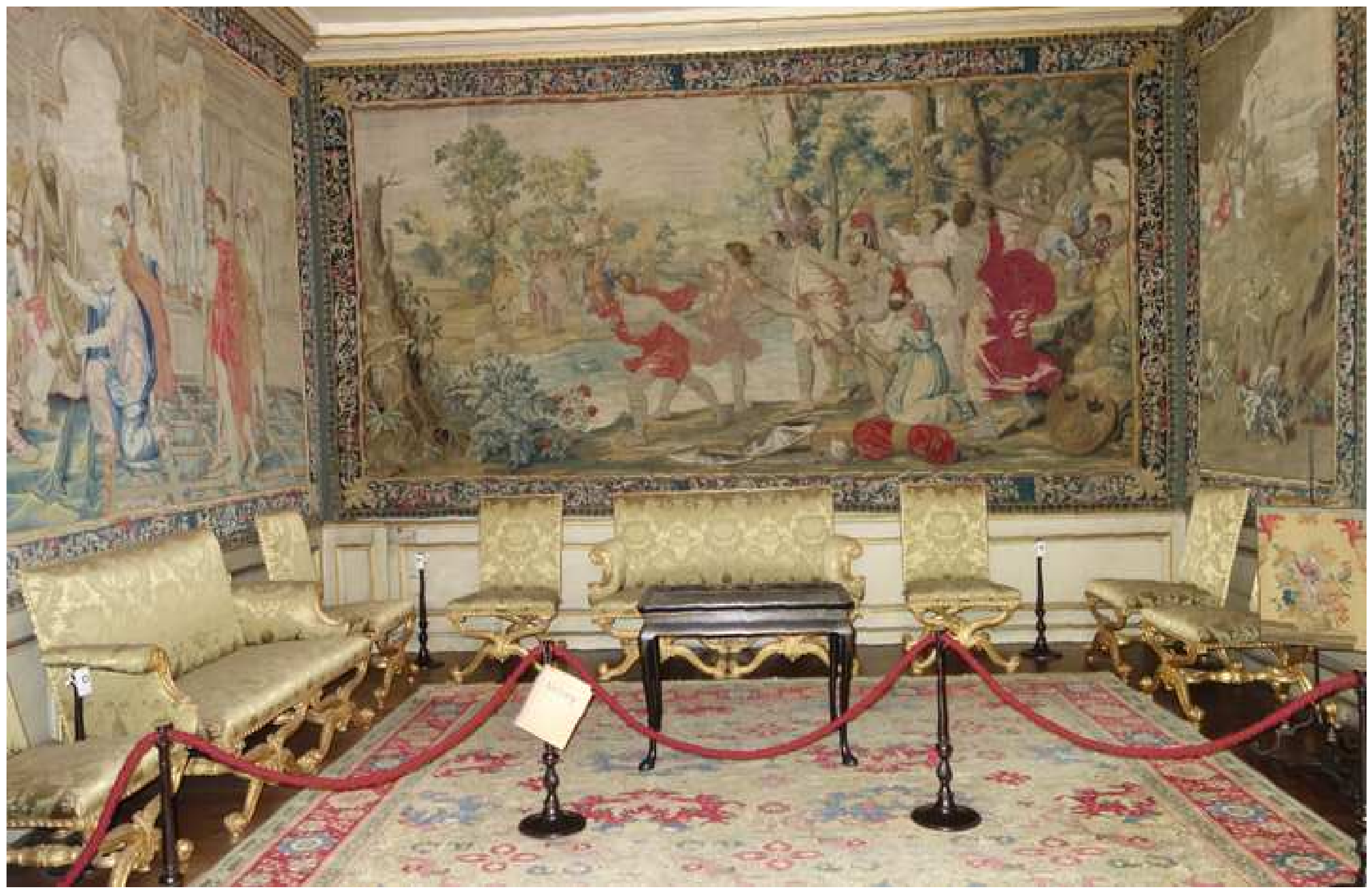




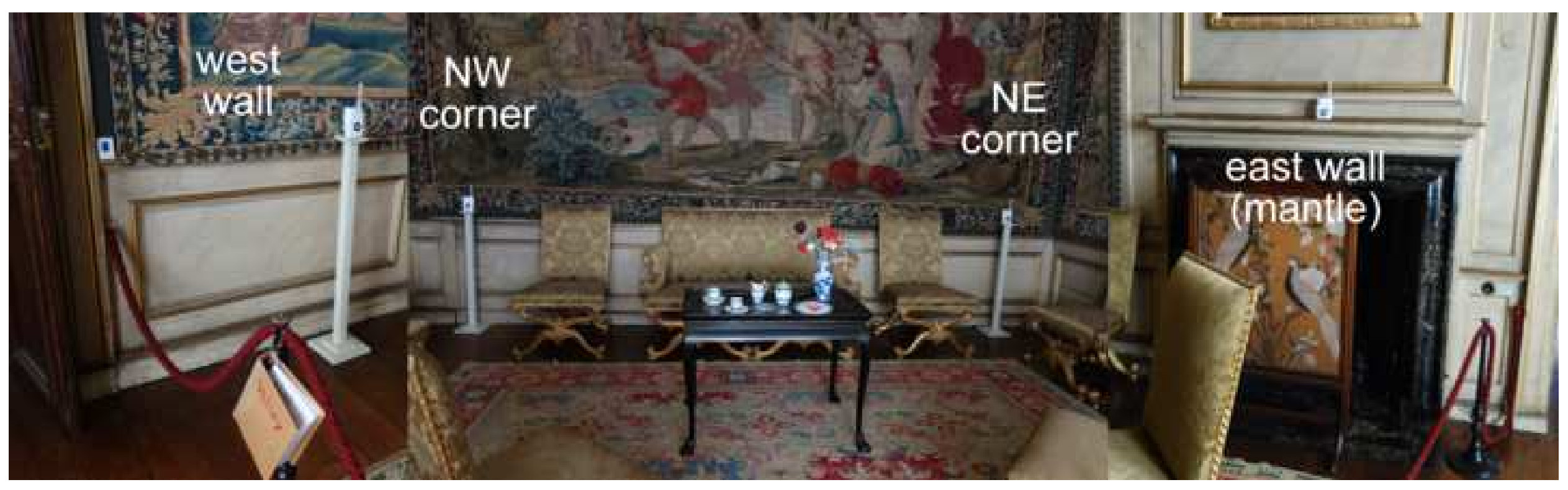



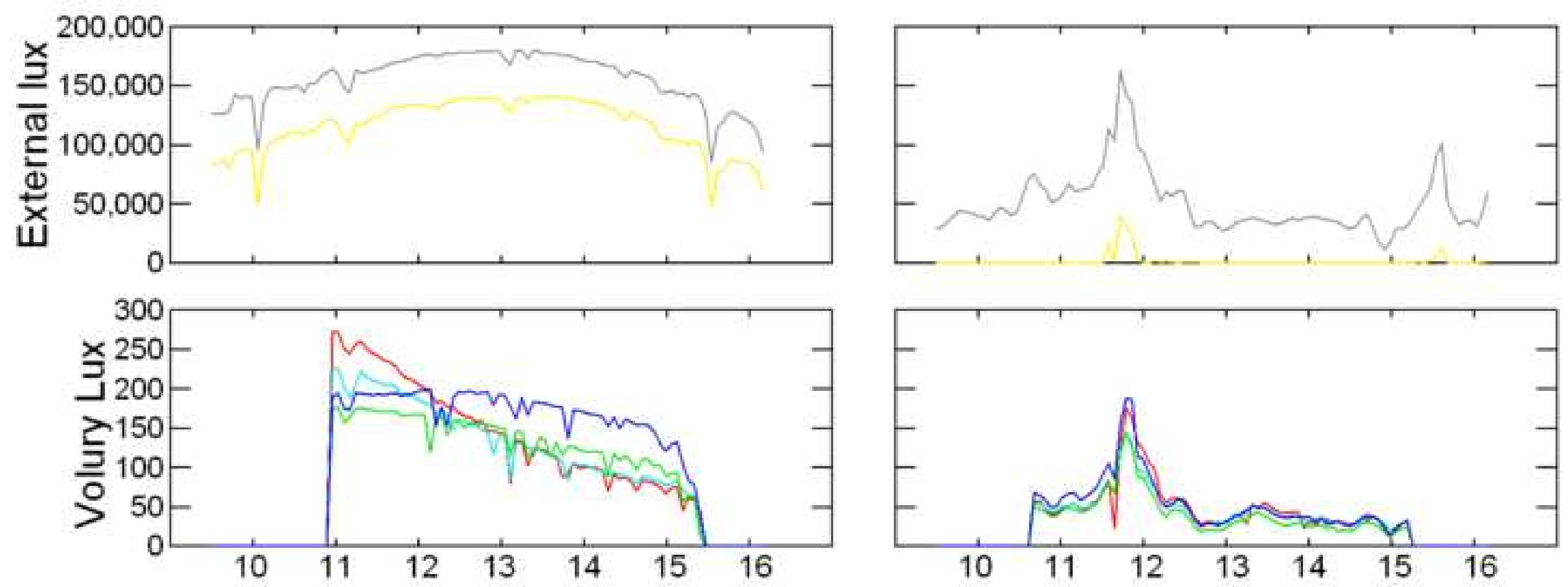